\title{
Anthropic pressure due to lost fishing gears and marine litter on different rhodolith beds off the Campania Coast (Tyrrhenian Sea, Italy)
}

\author{
Francesco Rendina, Federica Ferrigno*, Luca Appolloni, Luigia Donnarumma, \\ Roberto Sandulli, Giovanni Fulvio Russo
}

\author{
Department of Science and Technology, University of Naples "Parthenope", Centro Direzionale, \\ Is. C4, 80143 Naples, Italy \\ National Interuniversity Consortium for Marine Sciences (CoNISMa), 00196 Rome, Italy \\ *Corresponding author e-mail: F. Ferrigno; federica.ferrigno@uniparthenope.it
}

Received: 9 March 2020 / Accepted: 23 May 2020

\begin{abstract}
Impact of fishing gears and marine litter is a recognized global socio-ecological issue. Little is known about the extent of the problem in the Mediterranean seabed; even less information is available regarding litter distribution and its effects on deep rhodolith beds. Indeed, Mediterranean rhodolith beds are often remote and not yet sufficiently explored habitats, despite being internationally protected and recognized among the most important benthic communities for biodiversity maintenance. In this study, a quantitative assessment of marine litter and lost fishing gears, observed using a remotely operated vehicle, was carried out in 6 sites off the Campania Coast (Tyrrhenian Sea) characterized by different rhodolith covers. A negative correlation between abundance and richness of both marine litter and abandoned fishing gears with respect to the rhodolith cover was detected, suggesting that indirect human pressure along the coasts and direct effect of fishing activities might negatively damage these habitats. In fact, a lot of abandoned fishing gears and litter were recorded in all the 4 sites of the Gulf of Naples, confirming the high impact of maritime activities in this overcrowded area. Particularly, the Secchitiello site showed a very low mean cover of rhodoliths $(<5 \%)$ in concurrence with the highest abundance of lost fishing gears and litter. On the contrary, the lowest abundance of fishing gears and litter was recorded in the 2 sites along the Cilento coast, possibly due to the relatively low maritime activities in this poorly inhabited area. In conclusion, this work gives new insights into the anthropic pressure due to marine litter and fishing on deep Mediterranean rhodolith beds, and provides useful data for their management and conservation.
\end{abstract}

Keywords: deep biogenic habitats, coralline red algae, ROV, habitat degradation, human impacts, marine debris, Mediterranean Sea

\section{Introduction}

Rhodolith beds (RBs) are biogenic calcareous habitats formed by the aggregation of unattached, non-geniculate coralline algae (Corallinophycidae, Rhodophyta). In the Mediterranean Sea, together with Posidonia meadows, coralligenous and vermetid bioconstructions, they are considered as extremely biodiverse benthic habitats of high conservation and economic value (Ballesteros E., 2006; Basso et al., 2016; Franzese et al., 2017; Vassallo et al., 2017; Donnarumma et al., 2018; Buonocore et al., 2018, 2019, 2020a, 2020b), supporting a high diversity of associated species, some of which are commercially important (Soto, 1990; Mannino et al., 2002; Castriota et al., 2003, 2005; Templado et al., 2002; Hall-Spencer et al., 2003). These habitats are often affected by degradation and loss of structural heterogeneity due to anthropogenic disturbances, at both global scale, such as climate change, which will likely 
impact coralline algae in the near future (Ragazzola et al., 2012, 2016; Donnarumma et al., 2014; Rendina et al., 2019; Rindi et al., 2019), and local one, such as fishing activities, that causes mechanical impact and sediment accumulation (Marrack, 1999; Bordehore et al., 2000, 2003; Kamenos et al., 2003; Foster et al., 2013). In fact, despite their hard carbonate thallus, rhodoliths are often fragile (particularly mäerl forming species), and with low growth rates, of the order of just $1 \mathrm{~mm}$ year-1 (also depending on the coralline alga species, and the light intensity and temperature; Blake and Maggs, 2003; Martin and Gattuso, 2009; Foster et al., 2013). For this reason, RBs are particularly affected by mechanical damages due to bottom fisheries (i.e. dredging, fishing gears, bottom trawling), which can result in a reduction of the rhodolith cover, size and structure, loss of living thalli, and eventually transition into sand flats, characterized by a lower diversity and abundance of associated flora and fauna (Kaiser et al., 2001; Hall-Spencer and Moore, 2000; Bordehore et al., 2000, 2003; Hall-Spencer et al., 2002, 2003; Fosså et al., 2002; Steller et al., 2003; Blanchard et al., 2004). Moreover, sediment re-suspension due to fishing causes habitat degradation with burial and anoxia phenomena (Watling and Norse, 1998; Hall-Spencer and Moore, 2000; Foster et al., 2013; Bo et al., 2014). Fishing may also cause severe modifications of structure and functioning of deep ecosystems, leading to a shift in species composition towards opportunistic species with faster growth rates (Harris and Poiner, 1991; MacDonald et al., 1996; Schiaparelli et al., 2001; Clark and Koslow, 2007; Daskalov et al., 2007; Gilman et al., 2012). Additionally, fishing gears and marine litter produce an impact when they are abandoned in the environment, with a large variety of marine organisms damaged by entanglement and ingestion (Carr, 1987; Matsuoka et al., 2005; Brown and Macfadyen, 2007; Gall and Thompson, 2015; Vieira et al., 2015). Hence, the accumulation of abandoned fishing gears and litter is considered as one of the major causes of degradation of the marine environment at global scale, and several studies are trying to estimate their distribution, composition and abundance, and to evaluate their impacts on marine ecosystems (Watters et al., 2010; Galgani et al., 2015; Gall and Thompson, 2015; Vieira et al., 2015).

Only in the last decades, the importance of RBs and their high vulnerability to human pressures have been recognized, and several legal instruments have been adopted for the protection of RBs in European Seas. The first European initiative to protect these habitats was the Habitats Directive 92/43/EEC, which included the two fragile mäerl species, Phymatolithon calcareum (Pallas) W.H. Adey \& D.L. McKibbin ex Woelkering \& L.M. Irvine (1986) and Lithothamnion corallioides (P. Crouan \& H. Crouan) P. Crouan \& H. Crouan (1867), among those species affected by exploitation of marine resources and for which Member States have to ensure effective conservation meas- ures (Basso et al., 2016). In 2006, the Council Regulation 1967/2006 banished some specific bottom fishing gears on coralligenous and RBs (Council of the European Union, 2006). However, the lack of information available on RB spatial distribution makes difficult the effective application of this Regulation (Basso et al., 2016). Finally, Mediterranean RBs have been recently included among the habitats of special interest within the Marine Strategy Framework Directive (MSFD-2008/56/EC), aiming at achieving the 'Good Environmental Status' (GES) of all marine waters by 2020 (European Parliament and Council of the European Union, 2008; European Commission, 2010; Basso et al., 2016). Thus, the assessment of coralline algae distribution and biodiversity has been included within the monitoring protocol as descriptor to evaluate the GES (Basso et al., 2016). Moreover, among the eleven qualitative descriptors of GES (listed in Annex I of the MSFD), one of them concerns marine litter.

Despite the RBs vulnerability and value, both ecological and economic, there are very few studies about their distribution and characterization in the Mediterranean Sea (Basso et al., 2017), and even less information is available on the anthropic disturbances affecting these fragile habitats. This information gap is probably due to the remoteness of these habitats and the difficulties in observing and sampling organisms by scuba diving, compared to extraMediterranean shallower beds (Basso et al., 2014, 2016). Recent technological advances in Remotely Operated Vehicles (ROVs) allow to monitor deep sea habitats (e.g. coralligenous bioconstructions and RBs) on a wide area, with non-destructive and standardized protocols, based on computerized analysis of high resolution videos and photos (Aguilar et al., 2009; Bo et al., 2014; Ferrigno et al., 2017, 2018, 2020). ROV investigations have also been successfully performed to obtain quantitative data on benthic marine litter (Bergmann and Klages, 2012; Angiolillo et al., 2015) and to evaluate the impact of fishing activities, through lost gears, in coastal ecosystems (Bo et al., 2014; Cattaneo-Vietti et al., 2016; Ferrigno et al., 2017, 2018).

Despite Campania Coast (Italy, Tyrrhenian Sea) is known to be characterized by a high level of coastal urban population, tourism, and commercial fishing, there are no data available on the abundance of marine litter and fishing pressure on its RBs. The aim of this study is to fill this lack of information by ROV imaging technique and to assess the entity of the anthropic pressure produced by marine litter and fishing gears on deep RBs (40-80 m depth) recorded off the Campania Coast. 


\section{Materials and methods}

\section{Study area}

Surveys have been carried out in 2017 and 2018, in a depth range between 42 and $78 \mathrm{~m}$, in six sites off the Campania Coast. The investigation sites were chosen both from the previous records of coralline algal deposits along the Campania Coast (Babbini et al., 2006; Toscano et al., 2006; Gambi et al., 2009; Savini et al., 2012), and from the empirical knowledge of fishermen. In detail, four sites were selected within the overcrowded Gulf of Naples (Fig. 1A): Capri (40³2'20.545'N, 14¹3'17.653'"E), Punta Campanella (40³2'20.545'N N, 14 $\left.{ }^{\circ} 13^{\prime} 17.653^{\prime \prime} \mathrm{E}\right)$, Secchitiello (40 $\left.34^{\prime} 45.538^{\prime \prime} \mathrm{N}, 1^{\circ} 17^{\prime} 15.261^{\prime} \mathrm{E}\right)$, Ischia $\left(40^{\circ} 46^{\prime} 34.774^{\prime \prime} \mathrm{N}, 13^{\circ} 53^{\prime} 49.401 ' \mathrm{E}\right)$; and two sites off the poorly inhabited Cilento Coast (Fig. 1B): Acciaroli A $\left(40^{\circ} 8^{\prime} 9.582^{\prime \prime} \mathrm{N}, 15^{\circ} 3^{\prime} 46.011^{\prime \prime} \mathrm{E}\right)$ and Acciaroli B $\left(40^{\circ} 6^{\prime} 37.685^{\prime \prime} \mathrm{N}, 15^{\circ} 3{ }^{\prime} 39.149^{\prime \prime} \mathrm{E}\right)$.

\section{ROV data acquisition and analysis}

Following the MSFD protocols for RBs monitoring, data were collected by a Remotely Operated Vehicle (ROV
"Perseus" of Ageotec) equipped with a high definition video camera (DVS-3000 high definition), 2 lights, 2 parallel laser beams at the fixed distance of $14.5 \mathrm{~cm}$ for the evaluation of the dimensions. The ROV also hosted a further camera with displayed navigation data, obtained by the underwater positioning system USBL (Ultra Short Base Line System), interfaced with the on-board navigation system. This equipment allows to determine the real time geographical position and depth of the ROV videos.

At each site, 3 video-transects were carried out, with a length of $200 \mathrm{~m}$ each (covering an area of $1800 \mathrm{~m}^{2}$ ) and a distance of at least $50 \mathrm{~m}$ from each other. HD videos by ROV were analysed using the software VisualSoft ${ }^{\circ}$. A visual assessment of the sea bottom, characterized by rhodolith presence, was carried out on 60 images for site (20 images for video-transect), for a total of 360 analysed video frames. The video frames were obtained extrapolating images from the video tracks using the software DVDVideoSoft ${ }^{\circledR}$. Videos and photos analysis were carried out according to the standardized monitoring protocol for deep Mediterranean RBs, developed within the MSFD.

Video frames were analysed in order to define the percentage cover of red calcareous algae and the ratio of total live $v s$ dead rhodoliths (as indicator of the RB vital-

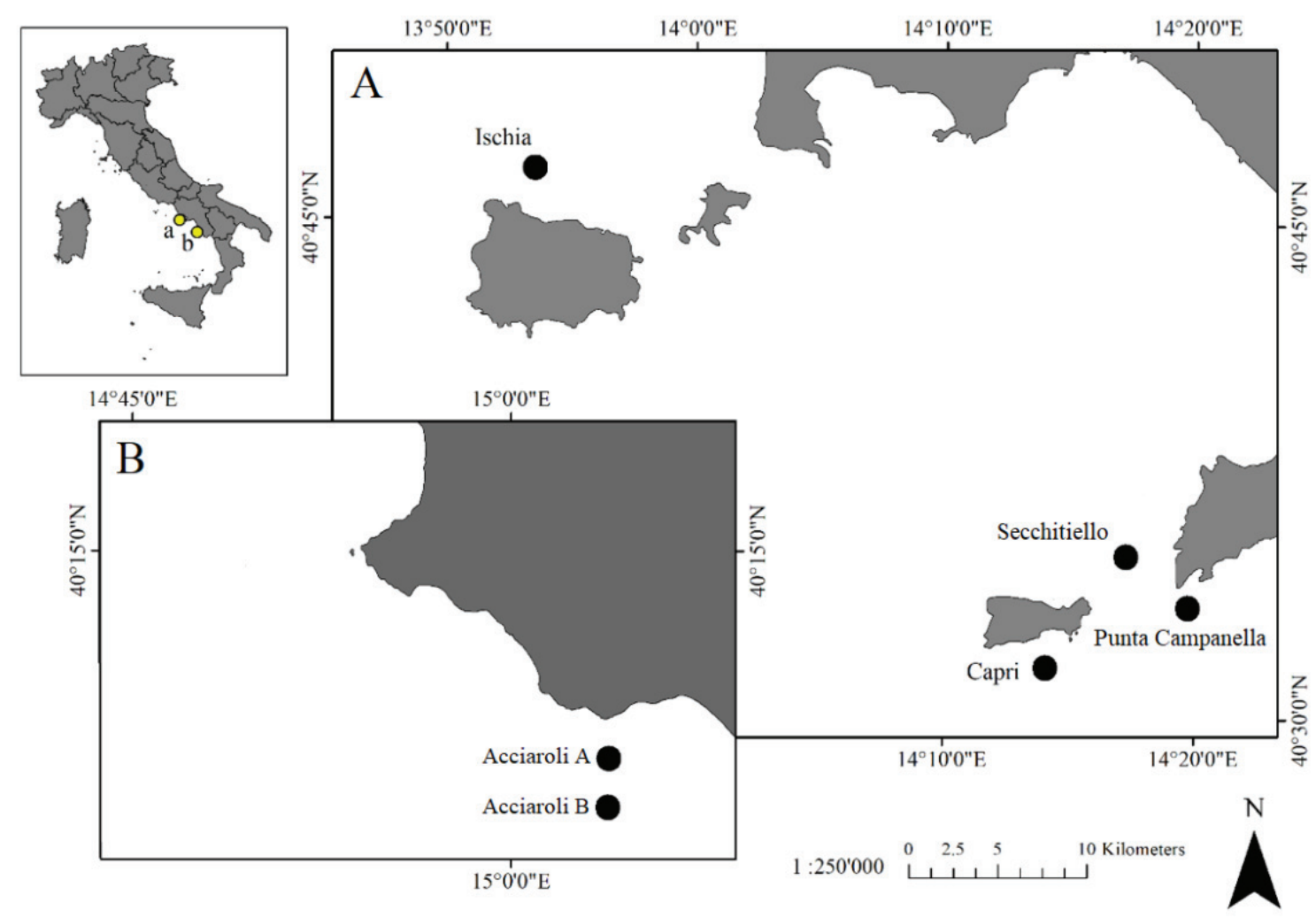

Fig. 1. Map of the sampling sites along the Campania Coast (Tyrrhenian Sea, Italy). (A) Gulf of Naples: Capri, Punta Campanella, Secchitiello and Ischia sites. (B) Cilento Coast: Acciaroli A and B sites 
ity; Peña and Barbara, 2010). Rhodoliths were considered dead when thalli were totally white. Fishing gears and litter abundances within each video-transect were calculated as proxy of the anthropic pressure. A total of 8 items were analysed. Fishing gears were divided into 4 items: nets, longlines, ropes, and other gears (such as anchors, traps, moorings, etc.). Litter was divided into 4 more items: plastic, glass, wood, and metal objects.

Data on rhodolith percentage cover and on live/dead rhodolith ratio, checked with the Shapiro-Wilk's test, were not normally distributed; thus non-parametric tests were applied. Specifically, univariate PERMANOVAs based on similarity matrixes, computed using Euclidean distances (Anderson, 2001; Terlizzi, et al. 2007; Guidetti et al., 2014), were performed in order to assess differences among sites. Pairwise tests were run in order to estimate the degree of similarity between pairs of sites.

Data on fishing gears and litter abundance met ANOVA requirements of normal distribution (Shapiro-Wilk's test) and equality of variance (Levene test); hence, a one-way ANOVA was performed to detect differences among sites. ANOVA was followed by Tukey's test to identify the statistically different groups of sites. Finally, to evaluate the effects of fishing gears and litter on the rhodolith cover and on live/dead rhodolith ratio, linear regressions were calculated. Analyses were performed using PAST software for Windows, version 3.16 (Hammer et al., 2001). Results are expressed as mean \pm standard deviation (DS), and $p$ is the significance.

\section{Results}

The sites were characterized by different rhodolith cover [PERMANOVA, $p<0.001]$. In particular, the examined video frames showed that Capri and Acciaroli A sites were characterized by a higher mean rhodolith cover $(66 \pm 14$ and
$60 \pm 4 \%$, respectively). Punta Campanella and Secchitiello showed by far a lower rhodolith cover $(5 \pm 28$ and $2 \pm 21$ $\%$, respectively). Intermediate cover values were recorded at Ischia and Acciaroli B (47 \pm 27 and $40 \pm 10 \%$, respectively). Sites were significantly different from each other also in terms of live/dead rhodolith ratio [PERMANOVA, $p<0.001]$. The lowest values of dead thalli compared to the live ones were observed in Capri, Punta Campanella, Secchitiello, and Acciaroli B, with dead thalli ranging from 12 to $17 \%$; while the highest percentages of dead thalli were detected at Ischia and Acciaroli A (26 and $76 \%$, respectively).

The quantitative analysis of fishing gears and marine litter items (Fig. 2A) showed significant differences among the investigated sites [ANOVA, $p=0.002$ ]. From the examined video-transects arise that Secchitiello was the site characterized by the highest abundance of both fishing gears and litter $\left(0.122 \pm 0.010\right.$ items per $\left.100 \mathrm{~m}^{2}\right)$. Intermediate values of items abundance were recorded in Capri, Punta Campanella, and Ischia $(0.071 \pm 0.040,0.076 \pm 0.012$, and $0.053 \pm 0.006$ items per $100 \mathrm{~m}^{2}$, respectively). The lowest abundances of items were observed in Acciaroli A and $\mathrm{B}\left(0.012 \pm 0.006\right.$ and $0.015 \pm 0.004$ items per $100 \mathrm{~m}^{2}$, respectively).

The qualitative analysis of fishing gears and marine litter items (Fig. 2B) showed that Secchitiello was the site characterized by the highest richness, with $63 \%$ of fishing items (i.e. nets, longlines, ropes, and other gears; Fig. 3AD) and $37 \%$ of litter items (i.e. plastic, glass, and metal objects; Fig. 3E-F). In the Capri, Punta Campanella and Ischia sites the relation fishing gears vs litter items was $53 \%$ vs $47 \%$, 35\% vs $65 \%$, and $83 \%$ vs $17 \%$, respectively. Finally, both sites off the Cilento coast, Acciaroli A and B, showed the lowest richness of items, with $100 \%$ of fishing items (i.e. longlines and ropes).
A

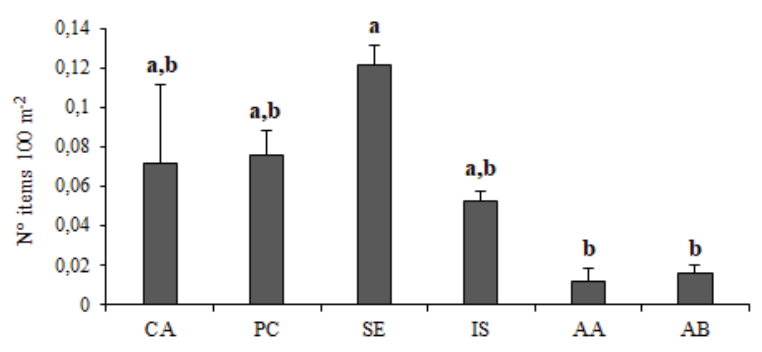

B

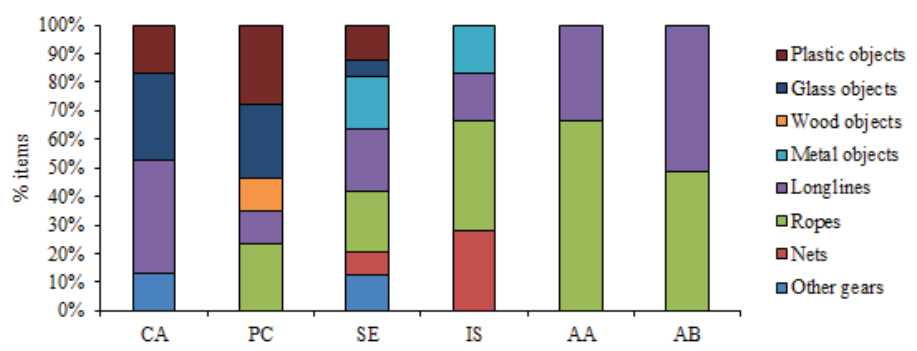

Fig. 2. (A) Number of total items per $100 \mathrm{~m}^{2}( \pm \mathrm{SD})$ in the different sites. (B) Percent abundances of items categories in each site. CA, Capri; PC, Punta Campanella; SE, Secchitiello; IS, Ischia; AA, Acciaroli A; AB, Acciaroli B. Different letters (a, b, and c) indicate significant differences between sites 

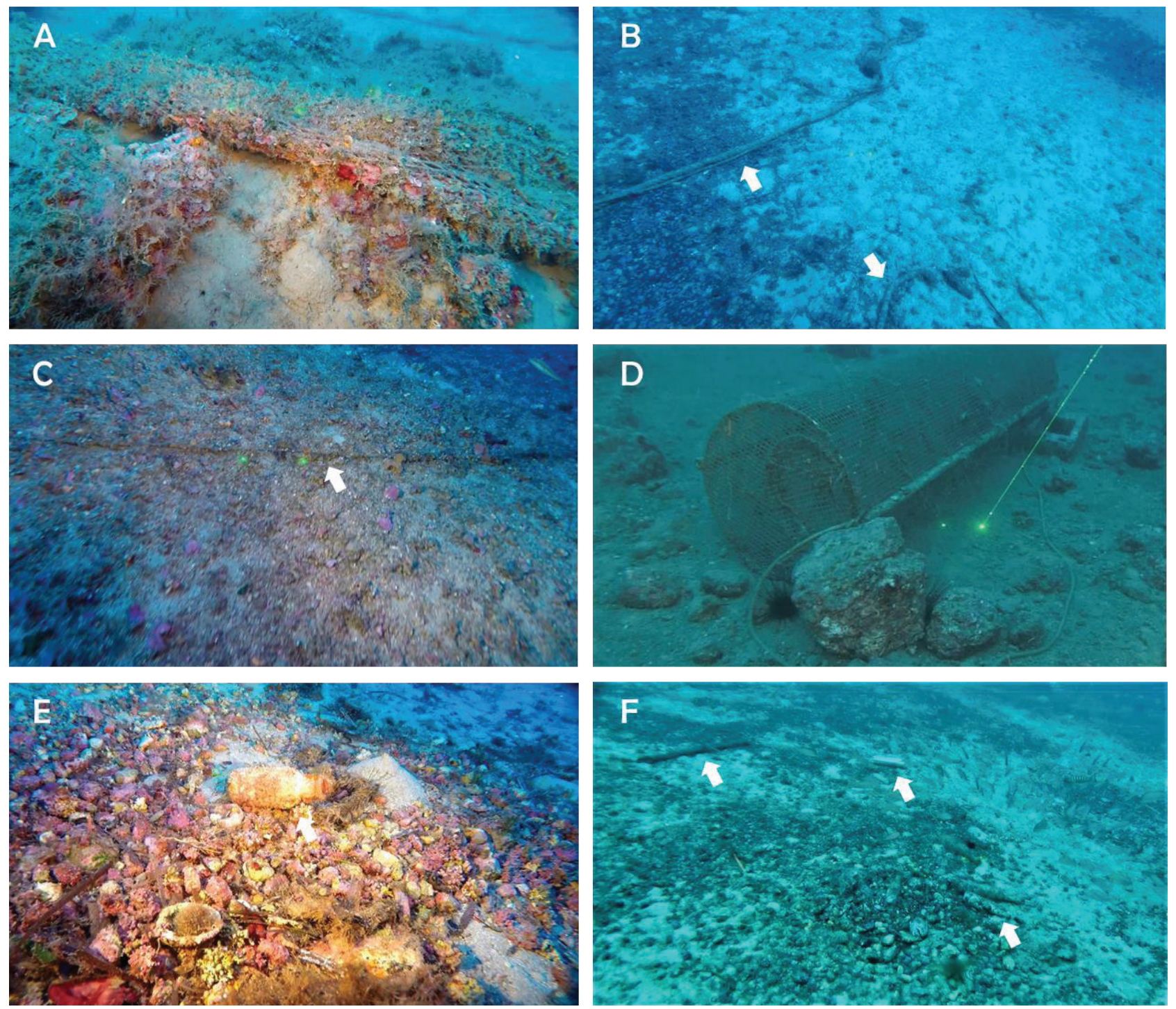

Fig. 3. ROV images of lost gears and litter on the studied rhodolith beds. (A) Derelict net covered in various epibionts such as red algae Corallinaceae and Peyssonneliaceae. (B) Lost rope (arrows). (C) Epibionted longline (arrow). (D) Abandoned fish trap. (E) Encrusted glass bottle. (F) Various plastic, glass, and metal objects (arrows)

As for the relation rhodolith cover vs items (Fig. 4A), a negative correlation was detected [Linear Regression, $p$ $=0.030]$, with the rhodolith cover values decreasing with increasing items abundance.
No correlation [Linear Regression, $p=0.341$ ] was observed between live/dead rhodolith ratio and items (Fig. 4B). 
A

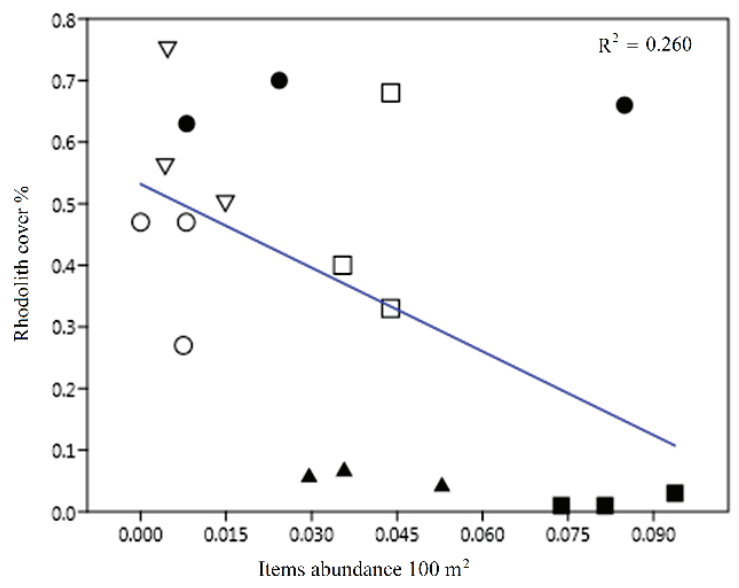

B

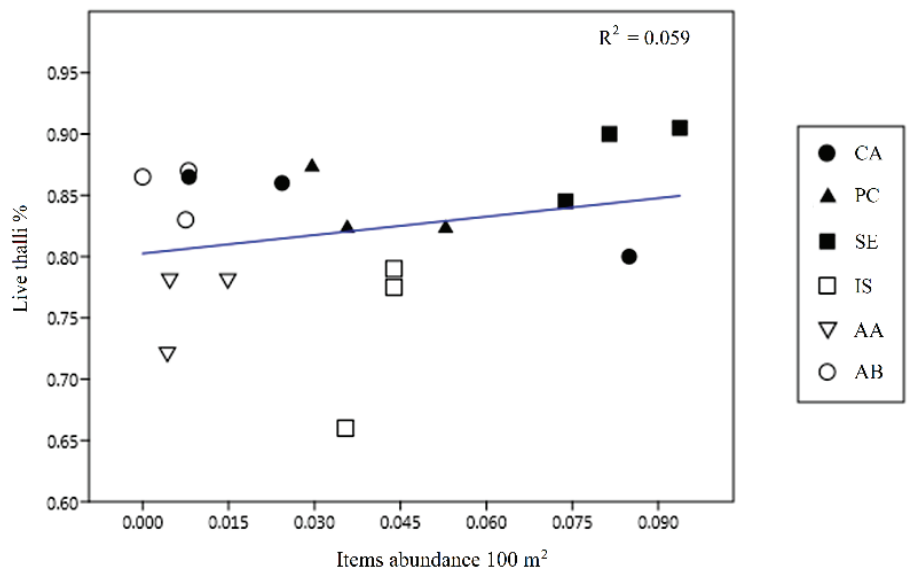

Fig. 4. Linear regression (A) between rhodolith cover and items abundance, and (B) between live/dead rhodolith ratio (expressed as percentage of live thalli on the total rhodolith cover) and items abundance. CA, Capri; PC, Punta Campanella; SE, Secchitiello; IS, Ischia; AA, Acciaroli A; AB, Acciaroli B. Equal symbols represent the three video-transects analysed for each site

\section{Discussion}

Despite the effects of fishing gears and litter on deep marine communities and habitats are still poorly known (Vieira et al., 2015), in the last decade, ROV surveys have provided strong evidences of fishing pressure and impact in the Mediterranean Sea (Bo et al., 2014; Ferrigno et al., 2018). This method is particularly useful also to obtain quantitative data on impacts of marine litter on deep-sea benthic communities (Angiolillo et al., 2015; Clark et al., 2016).

Litter (especially plastic materials) is considered among the predominant sources of marine pollution. It is an ecological and social concern, and a growing issue worldwide (Bauer et al., 2008; Löhr et al., 2017). It represents an important and persistent risk for marine ecosystems due to its non-biodegradability and its potential to be ingested by or to entangle organisms (Bo et al., 2014; Angiolillo et al., 2015; Ferrigno et al., 2017; Renzi et al., 2018, 2020). The impact of litter on RBs is poorly known. Additionally, RBs can be highly affected by bottom fisheries, both directly, by mechanical damages (i.e. dredging, fishing gears, bottom trawling; De Grave, 1999; Hall-Spencer and Moore, 2000), and indirectly, by smothering effects and degradation of water quality, representing a severe pressure for these habitats (Hall-Spencer et al., 2006; Sanz-Lázaro et al., 2011).

Our results suggested an important presence of lost fishing gears and litter in all the sites of the Gulf of Naples (i.e. Secchitiello, Punta Campanella, Capri, and Ischia) confirming the high fishing pressure in the area, as reported in previous studies (Russo et al., 2004; Sbrescia et al., 2008; Appolloni et al., 2018; Ferrigno et al., 2018).
The lower abundance of fishing gears and litter recorded in Cilento (i.e. Acciaroli A and B) is likely related to the low human population density characterizing this zone of the Campania region, representing a minor potential source of fishing gears and litter in comparison with the more populated coasts of the Gulf of Naples. This result is in line with several studies supporting the hypothesis that the occurrence of high densities of fishing gears and litter, in proximity to coastal urban areas, is correlated to the size of the nearby human population (Hess et al., 1999; Mordecai et al., 2011; Angiolillo et al., 2015). In Cilento RBs we found only two fishing items and no litter, therefore, these items are related to fishing activities and not to land-based activities.

Our findings indicated that Secchitiello, a small shoal of the Gulf of Naples, located offshore in the channel between the Sorrento Peninsula and Capri island, with a bathymetric range of 70-78 $\mathrm{m}$, was the site characterized by the highest abundance $\left(0.122 \pm 0.010\right.$ items per $\left.100 \mathrm{~m}^{2}\right)$ and richness (7/8) of items (both of fishing gears and litter). Fishing gears (i.e. nets, longlines, ropes, and other fishing litter) represents the $62 \%$ of the total items. This result is possibly related to the well known high abundance of fine fishes, making it attractive for local recreational and professional fisherman, as a consequence of the peculiar hydrological conditions and of the high biodiversity of the bottom communities (Ferrigno et al., 2017, 2018; Appolloni et al., 2020).

Some studies report plastic objects as the most diffused marine litter on the sea bottom (Galil et al., 1995; Galgani et al., 2000; Law et al., 2010; Miyake et al., 2011). Conversely, our work showed that the occurrence of abandoned items principally concerns fishing gears, particularly lost 
longlines, which were widespread in all the studied RBs. This finding is in line with several studies highlighting that fishing gears may be predominant in areas characterized by intense fishing activities (Chiappone et al, 2004, 2005; Watters et al., 2010; Mordecai et al., 2011; Bo et al., 2014; Angiolillo et al., 2015; Ferrigno et al., 2017). Hence, the investigated RBs seem to be particularly threatened by recreational and professional fishing pressure. It has to be considered that a nylon line can take up to six hundred years to decompose (Bianchi et al., 2004). Consequently, fishing gears, which are made of synthetic fibres, appear to be among the most dangerous items for marine wildlife, since they can cause entanglement and can also break down overtime into small fragments that can be ingested by organisms (Laist, 1987). Accordingly, the wide distribution of this type of gears represents a severe source of perturbation for benthic Mediterranean habitats, especially for the fragile RBs.

Despite fishing gears and litter are harmful to marine flora and fauna, these anthropogenic products can also provide artificial substratum for sessile organisms (Watters et al., 2010; Miyake et al., 2011). In this study, the majority of items was colonized by encrusting algae and invertebrates, while only few items, possibly recently abandoned or lost, did not show appreciable signs of sessile organism's colonization (Donohue et al., 2001; Saldanha et al., 2003).

Coherently to what before discussed, our analysis showed a negative correlation between abundance of items and rhodolith cover, with higher rhodolith cover in concurrence with a lower abundance and richness of fishing gears and litter items.

In conclusion, this work gives a further contribute toward a better understanding of the still poorly known distribution and effects of lost fishing gears and marine litter on RBs, a highly vulnerable habitat. These preliminary results highlight the importance of future monitoring programs, in order to provide management and conservation tools useful to develop protection measures and sustainable fishing, which are urgently necessary to preserve a fragile and poorly known marine ecosystem.

\section{Acknowledgements}

We would like to thank the head of the sea section of ARPA Campania Dr Lucio De Maio, the ARPAC crew members, and the ROV pilots and technicians of navigation informatics system of Subonica for field activities and data acquisition. This work was financed and supported by the National Inter-University Consortium for Marine Sciences (CoNISMa), within the Marine Strategy Framework Directive (MSFD-2008/56/EC) for the monitoring of rhodolith beds.

\section{References}

Aguilar R., Pastor X., Torriente A., Garcia S., 2009, Deepsea coralligenous beds observed with ROV on four seamounts in the western Mediterranean. In UNEPMAP-RAC/SPA, Proceedings of the 1st Mediterranean symposium on the conservation of the coralligenous and others calcareous bio-concretions. Tabarka, Tunis: CAR/ASP publishing: 147-149.

Anderson M., 2001, A new method for non-parametric multivariate analysis of variance. Austral ecology 26(1): 32-46.

Angiolillo M., di Lorenzo B., Farcomeni A., Bo M., Bavestrello G., Santangelo G., Cau A., Mastascusa V., Cau A. Sacco F., Canese S., 2015, Distribution and assessment of marine debris in the deep Tyrrhenian Sea (NW Mediterranean Sea, Italy). Marine pollution bulletin 92(1-2): 149-159.

Appolloni, L., Sandulli, R., Vetrano, G., Russo, G.F., 2018, A new approach to assess marine opportunity costs and monetary values-in-use for spatial planning and conservation; the case study of Gulf of Naples, Mediterranean Sea, Italy. Ocean \& coastal management 152: 135-144.

Appolloni L., Ferrigno F., Russo G.F., Sandulli R., 2020, $\beta$-Diversity of morphological groups as indicator of coralligenous community quality status. Ecological Indicators 109: 105840.

Babbini L., Bressan G., Massa-Gallucci A., Buia M.C., Gambi M.C., 2006, Segnalazione di una faciesa mäerl (Rhodophyta, Corallinales) lungo le coste dell'isola d'Ischia. Biologia Marina Mediterranea 13(1).

Ballesteros E., 2006, Mediterranean coralligenous assemblages: a synthesis of present knowledge. Oceanography and Marine Biology: An Annual Review 44: 123-195.

Basso D., Babbini L., Kaleb S., Falace A., Bracchi V.A., 2014, A protocol for the monitoring of Mediterranean rhodolith beds. In Proceedings of the 2nd Mediterranean Symposium on the conservation of Coralligenous and other Calcareous Bio-Concretions (Portorož, Slovenia, 29-30 October 2014).

Basso D., Babbini L., Kaleb S., Bracchi V., Falace A., 2016, Monitoring deep Mediterranean rhodolith beds. Aquatic Conservation: Marine and Freshwater Ecosystems 26(3): 549-561.

Basso D., Babbini L., Ramos-Esplá A.A., Salomidi M., 2017, Mediterranean Rhodolith Beds. In: RiosmenaRodríguez R., Nelson W., Aguirre J. (eds) Rhodolith/ Maërl Beds: A Global Perspective. Coastal Research Library, vol 15. Springer, Cham.

Bauer L.J., Kendall M.S., Jeffrey C.F.G., 2008, Incidence of marine debris and its relationships with benthic fea- 
tures in Gray's Reef National Marine Sanctuary, Southeast USA. Marine pollution bulletin 56: 402-413.

Bergmann M., Klages M., 2012, Increase of litter at the Arctic deep-sea observatory, HAUSGARTEN. Marine pollution bulletin 64: 2734-2741.

Bianchi C.N., Boero F., Carobene L., Carpaneto G., Fraschetti S., Morri C., Peccenini S., 2004, Problemi di conservazione e gestione. In: Cosentino, A., La Posta, A., Morandini, C., Muscio, G. (Eds.), Quaderni Habitat 7, Coste marine rocciose - La vita tra roccia e salsedine: 135-142.

Blake C., Maggs C.A., 2003, Comparative growth rates and internal banding periodicity of maerl species (Corallinales, Rhodophyta) from northern Europe. Phycologia 42(6): 606-612.

Blanchard F., LeLoc'h F. Hily C., Boucher J., 2004, Fishing effects on diversity, size and community structure of the benthic invertebrate and fish megafauna on the Bay of Biscay coast of France. Marine Ecology Progress Series 280: 249-260.

Bo M., Bava S., Canese S., Angiolillo M., Cattaneo-Vietti R., Bavestrello G., 2014, Fishing impact on deep Mediterranean rocky habitats as revealed by ROV investigation. Biological Conservation 171: 167-176.

Bordehore C., Borg J.A., Lanfranco E., Ramos-Esplá A., Rizzo M., Schembri P.J., 2000, Trawling as a major threat to Mediterranean maerl beds. In Symposium on marine vegetation (Ajaccio, 3-4 October 2000): 105.

Bordehore C., Ramos-Esplá A.A., Riosmena-Rodríguez R., 2003, Comparative study of two maerl beds with different otter trawling history, southeast Iberian Peninsula. Aquatic Conservation: Marine and Freshwater Ecosystems 13(S1): S43-S54.

Brown J., Macfadyen G., 2007, Ghost fishing in European waters: impacts and management responses. Marine Policy 31(4): 488-504.

Buonocore E., Picone F., Russo G.F., Franzese P.P., 2018. The scientific research on natural capital: A bibliometric network analysis. Journal of Environmental Accounting and Management 6 (4): 381-91.

Buonocore E., Picone F., Donnarumma L., Russo G.F., Franzese P.P., 2019. Modeling matter and energy flows in marine ecosystems using emergy and eco-exergy methods to account for natural capital value. Ecological Modelling 392: 137-46.

Buonocore E., Appolloni L., Russo G.F., Franzese P.P., 2020. Assessing natural capital value in marine ecosystems through an environmental accounting model: A case study in Southern Italy. Ecological Modelling 419: 108958.

Buonocore E., Donnarumma L., Appolloni L., Miccio A., Russo G.F., Franzese P.P., 2020. Marine natural capital and ecosystem services: An environmental accounting model. Ecological Modelling 424: 109029.
Castriota L., Gambi M.C., Zupo V., Sunseri G., 2003, Structure and trophic ecology of a population of Lysidice ninetta (Polychaeta) associated to rhodoliths off the island 112 of Ustica (Southern Tyrrhenian Sea). Biologia Marina Mediterrannea 10(2): 517-520.

Castriota L., Agamennone F., Sunseri, G., 2005, The mollusc community associated with maerl beds of Ustica Island (Tyrrhenian Sea). Cahiers de biologie marine 46(3): 289-297.

Carr A., 1987, Impact of non degradable marine debris on the ecology and survival outlook of sea turtles. Marine Pollution Bulletin 18(6): 352-356.

Cattaneo-Vietti R., Bo M., Cannas R., Cau A., Follesa C., Meliadò E., Russo G.F., Sandulli R., Bavestrello G., 2016, An overexploited Italian treasure: past and present distribution and exploitation of the precious red coral Corallium rubrum (L., 1758) (Cnidaria: Anthozoa). Italian Journal of Zoology 83(4): 443-455.

Chiappone, M., Swanson, D.W., Miller, S.L., Dienes, H., 2004, Spatial distribution of lost fishing gear on fished and protected offshore reefs in the Florida Keys National Marine Sanctuary. Caribbean Journal of Science 40: 312-326.

Chiappone M., Dienes H., Swanson D.W., Miller S.L., 2005, Impacts of lost fishing gear on coral reef sessile invertebrates in the Florida Keys National Marine Sanctuary. Biological Conservation 121: 221-230.

Clark M.R., Koslow, J., 2007, Impacts of fisheries on seamounts. In: Pitcher, T., Morato, T., Hart, P., Clark, M., Haggan, N., Santos, R. (Eds.), Seamounts: Ecology, Fisheries, and Conservation, Blackwell Fisheries and Aquatic Resources Series 12. Blackwell Publishing, Oxford, UK: 413-441.

Clark M.R., Althaus F., Schlacher T.A., Williams A., Bowden D.A., Rowden A.A., 2016, The impacts of deep-sea fisheries on benthic communities: a review. ICES Journal of Marine Science 73: i51-i69.

Council of the European Union, 2006, Council Regulation No. 1967/2006 concerning management measures for the sustainable exploitation of fishery resources in the Mediterranean Sea, amending Regulation (EEC) No 2847/93 and repealing Regulation (EC) No 1626/94. Official Journal of the European Union 409(30.12).

Daskalov G.M., Grishin A.N., Rodionov S., Mihneva V., 2007, Trophic cascades triggered by overfishing reveal possible mechanisms of ecosystem regime shifts. Proceedings of the National Academy of Sciences 104(25): 10518-10523.

De Grave S., 1999, The influence of sedimentary heterogeneity on within maërl bed differences in infaunal crustacean community. Estuarine, Coastal and Shelf Science 49(1): 153-163.

Donnarumma L., Lombardi C., Cocito S., Gambi M.C., 2014, Settlement pattern of Posidonia oceanica epi- 
bionts along a gradient of ocean acidification: an approach with mimics. Mediterranean Marine Science 15(3): 498-509.

Donnarumma L., Sandulli R., Appolloni L., Di Stefano F., Russo, G.F., 2018, Morpho-structural and ecological features of a shallow vermetid bioconstruction in the Tyrrhenian Sea (Mediterranean Sea, Italy). Journal of Sea Research 131: 61-68.

Donohue M.J., Boland R.C., Sramek C.M., Antonelis G.A., 2001, Derelict fishing gear in the Northwestern Hawaiian Islands: diving surveys and debris removal in 1999 confirm threat to coral reef ecosystems. Marine pollution bulletin 42:1301-1312.

European Commission, 2010, Commission decision of 1 September 2010 on criteria and methodological standards on good environmental status of marine waters. Official Journal of the European Union L 232/14.

European Parliament, Council of the European Union, 2008, Directive 2008/56/EC of the European Parliament and of the Council of 17 June 2008 establishing a framework for Community action in the field of marine environmental policy (Marine Strategy Framework Directive). Official Journal of the European Union L 1 .

Ferrigno F., Russo G.F., Sandulli R., 2017, Coralligenous Bioconstructions Quality Index (CBQI): a synthetic indicator to assess the status of different types of coralligenous habitats. Ecological Indicators 82: 271-279.

Ferrigno F., Appolloni L., Russo G.F., Sandulli R., 2018, Impact of fishing activities on different coralligenous assemblages of Gulf of Naples (Italy). Journal of the Marine Biological Association of the United Kingdom 98(1): 41-50.

Ferrigno F., Appolloni L., Rendina F., Donnarumma L., Russo G.F., Sandulli R., 2020, Red coral (Corallium rubrum) populations and coralligenous characterization within "Regno di Nettuno MPA" (Tyrrhenian Sea, Italy). The European Zoological Journal 87(1): 203-213.

Fosså J.H., Mortensen P.B., Furevik D.M., 2002, The deepwater coral Lophelia pertusa in Norwegian waters: distribution and fishery impacts. Hydrobiologia 471: 1-12.

Foster M.S., Filho G.M.A., Kamenos K.A., RiosmenaRodríguez R., Steller D.L., 2013, Rhodoliths and rhodolith beds. Research and Discoveries: Research and Discoveries: The Revolution of Science Through SCUBA: 143-155.

Franzese P.P., Buonocore E., Donnarumma L., Russo G.F., 2017. Natural capital accounting in marine protected areas: The case of the islands of Ventotene and S. Stefano (Central Italy). Ecological Modelling 360: 290-299.

Galgani F., Hanke G., Maes T., 2015, Global distribution, composition and abundance of marine litter. In Marine anthropogenic litter. Springer, Cham.: 29-56.

Galgani F., Leaute J.P., Moguedet P., Souplet A., Verin Y., Carpentier A., Goraguer H., Latrouite D., Andral B.,
Cadiou Y., Mahe J.C., Poulard J.C., Nerisson P., 2000, Litter on the sea floor along European coasts. Marine pollution bulletin 40: 516-527.

Galil B.S., Golik A., Türkay M., 1995, Litter at the bottom of the sea: a sea bed survey in the Eastern Mediterranean. Marine pollution bulletin 30: 22-24.

Gall S.C., Thompson R.C., 2015, The impact of debris on marine life. Marine pollution bulletin 92(1-2): 170-179.

Gambi M.C., Buia M.C., Massa-Gallucci A., Cigliano M., Lattanzi L., Patti F.P., 2009. The "pink mile": benthic assemblages of rhodolith and mäerl beds (Corallinales) off the Island of Ischia (Tyrrhenian Sea). In: Proceedings of the 1 st Mediterranean symposium on the conservation of the coralligenous and others calcareous bio-concretions (Tabarka, 15-16 January 2009). RAC/ SPA publ., Tunis: 197-200.

Gilman E., Chaloupka M., Read A., Dalzell P., Holetschek J., Curtice C., 2012, Hawaii longline tuna fishery temporal trends in standardized catch rates and length distributions and effects on pelagic and seamount ecosystems. Aquatic Conservation: Marine and Freshwater Ecosystems 22(4): 446-488.

Guidetti P., Baiata P., Ballesteros E., Di Franco A., Hereu B., Macpherson E., Micheli F., Pais A., Panzalis P., Rosenberg A.A., Zabala M., Sala E., 2014, Large-scale assessment of Mediterranean marine protected areas effects on fish assemblages. PLoS One 9(4): e91841.

Hall-Spencer J.M., Moore P.G., 2000, Scallop dredging has profound, long-term impacts on maërl habitats. ICES Journal of Marine Science 57: 1407-1415.

Hall-Spencer J.M., Allain V., Helge Fosså J., 2002, Trawling damage to Northeast Atlantic ancient coral reefs. Proceedings of the Royal Society of London. Series B: Biological Sciences 269(1490): 507-511.

Hall-Spencer J.M., Grall J., Moore P.G., Atkinson R.J.A., 2003, Bivalve fishing and maerl-bed conservation in France and the UK-retrospect and prospect. Aquatic Conservation: Marine and Freshwater Ecosystems 13(S1): S33-S41.

Hall-Spencer J.M., White N., Gillespie E., Gillham K., Foggo A., 2006, Impact of fish farms on maërl beds in strongly tidal areas. Marine Ecology Progress Series 326: 1-9.

Hammer Ø., Harper D.A.T., Ryan P.D., 2001, Past: palaeontological statistics software package for education and data analysis. Palaeontologia electronica 4(1): 1-9.

Harris A.N., Poiner I. R., 1991, Changes in species composition of demersal fish fauna of Southeast Gulf of Carpentaria, Australia, after 20 years of fishing. Marine Biology 111(3): 503-519.

Hess N.A., Ribic C.A., Vining I., 1999, Benthic marine debris, with an emphasis on fishery-related items, surrounding Kodiak Island, Alaska, 1994-1996. Marine pollution bulletin 38: 885-890. 
Kaiser J., Collie J., Hall S., Jennings S., Poiner I.R., 2001, Impacts of fishing gears on marine benthic habitats. In: Proc. Reykjavik Conf. Resp. Fish. Mar. Ecosys. Reykjavik, Iceland.

Kamenos N.A., Moore P., Hall-Spencer J., 2003, Substratum heterogeneity of dredged vs un-dredged maerl grounds. Journal of the Marine Biological Association of the United Kingdom 83(2): 411-413.

Laist D.W., 1987, Overview of the biological effects of lost and discarded plastic debris in the marine environment. Marine pollution bulletin 18: 319-326.

Law K.L., Morét-Ferguson S., Maximenko N.A., Proskurowski G., Peacock E.E., Hafner J., Reddy, C.M., 2010, Plastic Accumulation in the North Atlantic Subtropical Gyre. Science 329: 1185-1188.

Löhr A., Savelli H., Beunen R., Kalz M., Ragas A., Van Belleghem F., 2017, Solutions for global marine litter pollution. Current opinion in environmental sustainability 28: 90-99.

Mannino A.M., Castriota L., Beltrano A.M., Sunseri G., 2002, The epiflora of a rhodolith bed from the island of Ustica (Southern Tyrrhenian Sea). Flora Mediterranea 12: 11-28.

MacDonald D.S., Little M., Eno M.C., Hiscock K., 1996, Disturbance of benthic species by fishing activities: a sensitivity index. Aquatic Conservation: Marine and Freshwater Ecosystems 6(4): 257-268.

Marrack E.C., 1999, The relationship between water motion and living rhodolith beds in the southwestern Gulf of California, Mexico. Palaios: 159-171.

Martin S., Gattuso J.P., 2009, Response of Mediterranean coralline algae to ocean acidification and elevated temperature. Global Change Biology 15: 2089-2100.

Matsuoka T., Nakashima T., Nagasawa N., 2005, A review of ghost fishing: scientific approaches to evaluation and solutions. Fisheries Science 71(4): 691-702.

Miyake H., Shibata H., Furushima Y., 2011, Deep-Sea Litter Study Using Deep-Sea Observation Tools. In: Omori, K., Guo, X., Yoshie, N., Fujii, N., Handoh, I.C., Isobe, A., Tanabe, S. (Eds.), Interdisciplinary Studies on Environmental Chemistry- Marine Environmental Modeling \& Analysis: 261-269.

Mordecai G., Tyler P.A., Masson D.G., Huvenne V.A.I., 2011, Litter in submarine canyons off the west coast of Portugal. Deep-Sea Research Part II 58: 2489-2496.

Peña V., Barbara I., 2010, Seasonal patterns in the mäerl community of shallow European Atlantic beds and their use as a baseline for monitoring studies. European Journal of Phycology 45: 327-342.

Ragazzola F., Foster L.C., Form A., Anderson P.S., Hansteen T.H., Fietzke J., 2012, Ocean acidification weakens the structural integrity of coralline algae. Global change biology 18(9): 2804-2812.
Ragazzola F., Foster L.C., Jones C.J., Scott T.B., Fietzke J., Kilburn M.R., Schmidt D.N., 2016, Impact of high $\mathrm{CO}_{2}$ on the geochemistry of the coralline algae Lithothamnion glaciale. Scientific reports 6(1): 1-9.

Rendina F., Bouchet P.J., Appolloni L., Russo G.F., Sandulli R., Kolzenburg R., Putra A., Ragazzola F., 2019, Physiological response of the coralline alga Corallina officinalis L. to both predicted long-term increases in temperature and short-term heatwave events. Marine environmental research 150: 104764.

Renzi M., Blašković A., Bernardi G., Russo G.F., 2018, Plastic litter transfer from sediments towards marine trophic webs: a case study on holothurians. Marine pollution bulletin 135: 376-385.

Renzi M., Blašković A., Broccoli A., Bernardi G., Grazioli E., Russo, G.F., 2020, Chemical composition of microplastic in sediments and protected detritivores from different marine habitats (Salina Island). Marine Pollution Bulletin 152: 110918.

Rindi F., Braga J., Martin S., Peña V., Le Gall L., Caragnano A., Aguirre, J., 2019, Coralline algae in a changing Mediterranean Sea: how can we predict their future, if we do not know their present?. Frontiers in Marine Science 6: 723 .

Russo G.F., Ascione M., Franzese P.P., 2004, Analisi emergetica della Riserva marina di Punta Campanella: valutazione ecologico-economica del comparto pesca. Biologi Italiani 11: 63-70.

Saldanha H.J., Sancho G., Santos M.N., Puente E., Gaspar M.B., Bilbao A., Monteiro C.C., Gomez E., Arregi L., 2003, The use of biofouling for ageing lost nets: a case study. Fisheries Research 64: 141-150.

Sanz-Lázaro C., Belando M.D., Lázaro Marín-Guirao L., Navarrete-Mier F., Arnaldo M.A., 2011, Relationship between sedimentation rates and benthic impact on Maërl beds derived from fish farming in the Mediterranean. Marine Environmental Research 71: 22-30.

Savini A., Basso D., Bracchi V.A., Corselli C., Pennetta M., 2012, Maerl-bed mapping andcarbonate quantification on submerged terraces offshore the Cilento peninsula (Tyrrhenian Sea, Italy). Geodiversitas 34(1): 77-98.

Sbrescia L., Di Stefano F., Russo M., Russo G.F., 2008, Influenza della pesca sportiva sulle gorgonie nell'AMP di Punta Campanella. Biologia Marina Mediterranea 15: 172-173.

Schiaparelli S., Chiantore M., Novelli F., Drago N., Cattaneo-Vietti R., Albertelli G., 2001, Stable deep-sea benthos not so stable: long-term changes in a bathyal community in the Ligurian Sea. In: Faranda, F.M., Guglielmo, L., Spezie, G. (Eds.), Mediterranean Ecosystems: Structure and Processes. Springer Verlag, Italia: 340-346. 
Soto J., 1990, Vegetación algal sobre sustrato móvil de la zona circalitoral del sureste de la Península Ibérica: una aproximación. Folia Botanica Miscellanea 7: 43-49.

Steller D.L., Riosmena-Rodriguez R., Foster M.S., Roberts C.A., 2003, Rhodolith bed diversity in the Gulf of California: the importance of rhodolith structure and consequences of disturbance. Aquatic Conservation: Marine and Freshwater Ecosystems 13: S5-S20.

Templado J., Calvo M., García-Carrascosa A.M., Boisset F., Jiménez J., 2002, Flora y fauna de la Reserva Marina de las Islas Columbretes. Secretaría Gral. Pesca Marítima. $\mathrm{M}^{\circ}$ Agricultura, Pesca y Alimentación. Museo Nacional de Ciencias Naturales, CSIC: 263.

Terlizzi A., Anderson M.J., Fraschetti S., Benedetti-Cecchi L., 2007, Scales of spatial variation in Mediterranean subtidal sessile assemblages at different depths. Marine Ecology Progress Series 332: 25-39.

Toscano F., Vigliotti M., Simone L., 2006, Variety of coralline algal deposits (rhodalgal facies) from the Bays of Naples and Pozzuoli (northern Tyrrhenian Sea, Ita- ly). Geological Society, London, Special Publications 255(1): 85-94.

Vassallo P., Paoli C., Buonocore E., Franzese P.P., Russo G.F., Povero P., 2017. Assessing the value of natural capital in marine protected areas: A biophysical and trophodynamic environmental accounting model. Ecological Modelling 355: 12-17.

Vieira R.P., Raposo I.P., Sobral P., Gonçalves J.M., Bell K.L., Cunha M.R., 2015, Lost fishing gear and litter at Gorringe Bank (NE Atlantic). Journal of sea research 100: 91-98.

Watling L., Norse E.A., 1998, Disturbance of the seabed by mobile fishing gear: a comparison to forest clear cutting. Conservation Biology 12: 1180-1197.

Watters D.L., Yoklavich M.M., Love M.S., Schroeder D.M., 2010, Assessing marine debris in deep seafloor habitats off California. Marine Pollution Bulletin 60: 131-138. 